\title{
Pengaruh Online Travel Agent terhadap Pemesanan Kamar di Hyatt Regency Yogyakarta
}

\author{
Citra Tartilla Nurdita Putri ${ }^{1 *}$, Eman Sukmana ${ }^{2}$, I Wayan Lanang Nala ${ }^{3}$ Rinto Dwiatmojo ${ }^{4}$ \\ 1. citrajunip@gmail.com; ${ }^{2}$ emansukmana@polnes.ac.id;3.wayanlanang@polnes.ac.id, ${ }^{4}$ rinto_dwiatmojo@polnes.ac.id \\ ${ }^{1}$ Mahasisiwa, Jurusan Pariwisata Politeknik Negeri Samarinda, Kota Samarinda, 75136, Indonesia \\ ,2,3,4, Dosen Jurusan Pariwisata Politeknik Negeri Samarinda, Kota Samarinda, 75136, Indonesia \\ 1,2,3,4, Jl. DR. Ciptomangunkusumo, Kampus Gunung Lipan, Samarinda, Kalimantan Timur, Indonesia $75131 \mid$ Hot line: \\ PABX (+62541) 260588, FAX: (+62541) 260355
}

ARTICLE INFO (8 pt)

Article history:

Received

Revised

Accepted

Persyaratan Mengajukan E ISSN

Keywords: Room occupancy rates, Online Travel Agents, promotions, guests.

\section{ABSTRACT (10PT)}

The development of increasingly sophisticated and rapid technology has made people's lifestyles to change, one of the most striking things is the tendency to do activities in cyberspace, such as purchasing tickets online. Online hotel ticket purchases can be made through the E-Commerce site on the hotel's official website or through third party websites. E-Commerce is known as an Online Travel Agent, with the existence of an Online Travel Agent, prospective guests have a very diverse choice of hotels according to their wants and needs. Prospective guests can directly book hotel rooms and change their bookings easily. The aim of the author is to examine changes in guest behavior, especially guests who previously directly booked a room directly to the hotel, switch to using an Online Travel Agent and find out what promotional strategies hotels should do to increase the number of room bookings through Online Travel Agents. Promotion strategy analysis using SWOT analysis such as SWOT Matrix, IFAS, EFAS, Cartesian Diagram, Internal and External Matrix. The results of the analysis of internal factors and external factors show that the Hyatt Regency Yogyakarta hotel has a strong market competitive position in competition with other five star hotels. This shows that the hotel must continue to make efforts to improve product quality, facilities and services as well as maximize product sales.

\section{ABSTRAK}

Perkembangan teknologi yang semakin canggih dan pesat membuat gaya hidup masyarakat ikut berubah, salah satu hal paling mencolok adalah kecenderungan beraktivitas di dunia maya seperti pembelian tiket secara online. Pembelian online tiket hotel dapat dilakukan melalui situs E-Commerce pada website resmi hotel atau melalui website pihak ketiga. E-Commerce tersebut dikenal dengan istilah Online Travel Agent, dengan adanya Online Travel Agent calon tamu memiliki pilihan hotel yang sangat beragam sesuai dengan keinginan dan kebutuhan. Calon tamu bisa lansung memesan kamar hotel dan merubah pemesanannya dengan mudah. Tujuan penulis ingin meneliti perubahan perilaku tamu, terutama tamu yang dahulu lansung memesan kamar lansung ke hotel beralih menggunakan Online Travel Agent dan mengetahui strategi promosi yang seperti apa yang harus dilakukan oleh hotel untuk meningkatkan jumlah pemesanan kamar melalui Online Travel Agent. Analisis strategi promosi dengan menggunakan analisis SWOT seperti Matriks SWOT, IFAS, EFAS, Diagram Cartesius, Matriks Internal dan Eksternal. Hasil analisis faktor internal dan faktor eksternal maka diketahui bahwa hotel Hyatt Regency Yogyakarta memiliki posisi kompetitif pasar yang kuat

$$
\begin{aligned}
& \text { W : http://e-journal.polnes.ac.id/index.php/edutourism/ } \\
& \text { E : jurnal_edutourism@polnes.ac.id }
\end{aligned}
$$

Kata kunci: Tingkat hunian kamar, agen travel daring, promosi, tamu. 
dalam persaingan dengan hotel bintang lima lainnya. Hal ini menunjukkan hotel harus tetap melakukan upaya-upaya meningkatkan kualitas produk, fasilitas dan pelayanan serta melakukan penjualan produk secara maksimal.

Copyright $\odot 2019$ Politeknik Negeri Samarinda. All rights reserved.

\section{Pendahuluan}

Seiring dengan perkembangan zaman modern ini teknologi semakin meningkat. Dimana segala informasi dapat diketahui dengan cepat. Internet merupakan sarana elektronik yang dapat dipergunakan untuk berbagai aktivitas seperti komunikasi, riset, transaksi bisnis dan lainnya. Tingginya pertumbuhan pengguna internet adalah peluang bagi para pelaku bisnis untuk menawarkan produknya melalui Internet. Hal ini lebih dikenal dengan istilah E-Commerce. E-Commerce adalah kegiatan melakukan transaksi bisnis secara online melalui media internet dan perangkat-perangkat yang terintegrasi dengan Internet (Laudon, 2012). Berkembangnya pengguna E-Commerce juga terjadi pada industri pariwisata. Jumlah penjualan melalui E-Commerce dalam industri pariwasata terus mengalami peningkatan terutama pemesanan online pada area transportasi, akomodasi, paket wisata, dan penawaran wisata lainnya (Gratzer et al, 2004).

Pembelian online (online booking) tiket hotel dapat dilakukan melalui situs $E$ Commerce pada website resmi hotel atau melalui website pihak ketiga. E-Commerce tersebut dikenal dengan istilah Online Travel Agent. Dengan adanya Online Travel Agent calon tamu memiliki pilihan hotel yang sangat beragam sesuai dengan keinginan dan kebutuhan. Calon tamu bisa lansung memesan kamar hotel dan merubah pemesanannya dengan mudah.

Hyatt Regency Yogyakarta adalah salah satu hotel bintang 5 yang ada didaerah Provinsi Yogyakarta, untuk itu Hyatt Regency Yogyakarta harus menganalisis segmentasi pasar untuk menentukan targer pasar sehingga dapat menerapkan strategi penjualan untuk menarik pelanggan. Strategi pemasaran sangat diperlukan untuk menentukan keberhasilan suatu bisnis dalam meningkatkan pendapatan dan memberikan pelayanan yang memuaskan bagi tamu Perkembangan teknologi yang semakin canggih dan pesat membuat gaya hidup masyarakat ikut berubah, salah satu paling mecolok adalah kecenderungan beraktivitas di dunia maya seperti pembelian tiket secara online. Oleh sebab itu, masyarakat beralih kepada Online Travel Agent karena sangat praktis dan dapat dilakukan dimana saja dibandingkan dengan travel agent konvesional.

\section{Tinjauan Pustaka}

\section{A. E-Commerce}

McLeod Pearson (2008:59) mendefinisikan Perdagangan elektronik atau yang disebut juga E-Commerce, adalah penggunaan jaringan komunikasi dan komputer untuk melaksanakan proses bisnis. Pandangan populer dari E-Commerce adalah penggunaan internet dan komputer dengan browser Web untuk membeli dan menjual produk. Perdagangan elektronik E-Commerce mencangkup proses pembelian, penjualan, transfer, atau pertukaran produk, layanan atau informasi melalui jaringan komputer, termasuk internet (Turban, 2012:38). ECommerce sering dianggap sederhana untuk merujuk kepada pembelian dan penjualan yang memakai internet (Chaffey, 2009:10).

\section{B. Online Travel Agent}

Online Travel Agent adalah agen perjalanan yang berperan sebagai media promosi dan penjualan secara online melalui website. Website Online Travel Agent adalah website yang dikelola oleh OTA yang mendistribusikan dan memfasilitasi pemesanan ke pihak penyedia usaha pariwisata (Australian Tourism Data Warehouse 2013).

Pengertian Online Travel Agent menurut (Malla, 2016): 
"Online Travel Agency, commonly known as OTA covers wide Range of Travel service apart from online reservations and agent management. They generally go with a complete travel portal development with all the global travel related services like flight reservations, hotel reservations, vacations packages, transfers, fancy bookings, car rentals, mobile recharge, insurance, DTH recharge, bill payments. Social selling, mobile app version and many more. Most of them go with B2B2C business model. OTA as generally contract with many suppliers and individual LCCs to bring vast choice of contents in their website."

\section{Extranet}

Pengertian extranet menurut Turban dalam King dan kawan-kawan (2010) extranet adalah jaringan yang menggunakan internet untuk menghubungkan beberapa intranet secara aman. Menurut O'Brien dan Markas (2011) extranet adalah penghubung jaringan yang menggunakan teknologi internet untuk menghubungkan intranet dari suatu bisis dengan intranet dari pelanggan, pemasok atau mitra bisnis lainnya. Jadi dari beberapa pendapat diatas, dapat ditarik kesimpulan bahwa extranet adalah jaringan yang menggunakan teknologi internet untuk menghubungkan beberapa intranet dari suatu bisnis dengan intranet pelanggan, pemasok atau mitra bisnis lainnya.

\section{Hunian Kamar}

Tingkat hunian kamar atau di hotel biasa disebut dengan hotel room occupancy merupakan suatu keadaan sampai sejauh mana jumlah kamar terjual, jika diperbandingkan dengan seluruh jmlah kamar yang mampu terjual. Ratio occupancy merupakan tolok ukur keberhasilan hotel dalam menjual produk utamanya, yaitu kamar.

\section{E. Bauran Pemasaran}

Bauran pemasaran menurut Kotler dan Armstrong (2015:76): “The set of tactical marketing tools product, price, place and promotion that the firm blends to produce the response it wants in the target market".

Kutipan tersebut dapat diartikan bahwa bauran pemasaran adalah seperangkat alat dalam menggunakan strategi pemasaran yang berupa produk, harga, tempat dan cara perusahaan untuk mempromosikan hasil barang atau jasa agar mendapat respons yang diinginkan dalam target pasar. Pengertian unsur-unsur bauran pemasaran adalah sebagai berikut: Produk, Harga, Saluran Distribusi/Lokasi, dan Promosi.

\section{Metode Penelitian}

\section{A. Objek Penelitian}

Penelitian ini dilakukan pada Hotel Hyatt Regency Yogyakarta yang berlokasi di Jl. Palagan Tentara Pelajar, Kelurahan Sariharjo, Kecamatan Ngaglik, Kabupaten Sleman, Daerah Istimewa Yogyakarta. Dalam tugas akhir ini peneliti mengangkat judul mengenai strategi penjualan. Waktu pelaksanaan penelitian dimulai pada bulan Juli 2019 hingga bulan Januari 2020, objek penelitian ini adalah strategi penjualan yang perlu dilakukan oleh Hyatt Regency Yogyakarta dalam meningkatkan hunian kamar.

\section{B. Teknik Pengumpulan Data}

Metode atau cara yang digunakan dalam mengumpulkan sumber data adalah dengan:

\section{a. Studi Pustaka}

Studi kepustakaan ini dimaksudkan sebagai daftar penelitian dalam pembuatan analisis teori. Oleh karena itu penulis juga mencari pendapat dari orang-orang yang pernah diuji dan diakui kebenarannya yang ada hubungannya dengan pembahasan karya tulis ini.

\section{b. Studi Lapangan}

Pengumpulan data secara lansung yang dilakukan pada obyek penelitian sebagai data primer. Pada pengumpulan data ini penulis akan terjun lansung ke Hyatt Regency Yogyakarta. Adapun metodenya sebagai berikut:

\section{- Wawancara (Interview)}

Suatu metode pengumpulan data dengan cara melakukan wawancara lansung dengan Bapak Yudi Karyono selaku Reservations Manager Hyatt Regency Yogyakarta dan Bapak Rendra Novianto selaku Team Leader Reservations di Hyatt Regency Yogyakarta.

\section{- Observasi}

Yaitu pengamatan yang dilakukan secara lansung terhadap pemesanan kamar melalui Online Travel Agent. 


\section{Teknik Analisis SWOT}

Menurut Irham Fahmi (2014:260), untuk menganalisis secara lebih dalam mengenai analisis SWOT, maka perlu dilihat dari faktor eksternal maupun internal sebagai bagian penting dalam analisis SWOT, yaitu:

\section{Faktor Eksternal}

Faktor eksternal ini mempengaruhi terbentuknya oppurtunities and threats $(\mathrm{O}$ and T). Dimana faktor ini menyangkut dengan kondisi-kondisi yang terjadi di luar perusahaan yang mempengaruhi dalam pembuatan keputusan perusahaan. Faktor ini mencakup lingkungan industri dan lingkungan bisnis makro, ekonomi, politik, hukum, teknologi, kependudukan dan sosial budaya.

\section{Faktor Internal}

Faktor Internal ini mempengaruhi terbentuknya strengths and weakness ( $\mathrm{S}$ and W). Dimana faktor ini menyangkut dengan kondisi yang terjadi dalam perusahaan, yang mana ini turut mempengaruhi terbentuknya pembuatan keputusan perusahaan. Faktor Internal ini meliputi semua macam manajemen fungsional: pemasaran, keuangan, operasi, sumber daya manusia, penelitian, dan pengembangan, sistem informasi manajemen dan budaya perusahaan.

\section{Matriks Faktor Strategi}

Menurut Burani (2013:25) bahwa cara menentukan bobot setiap indikator dari faktorfaktor internal maupun eksternal yaitu dengan menggunakan Skala Prioritas mulai dari angka 4 (sangat penting) sampai dengan 1 (tidak penting) pada variabel bersifat positif. Berikut ini tabel yang memperlihatkan fenomena-fenomena yang menjadi faktorfaktor internal dalam penelitian ini.

\section{Hasil dan Pembahasan}

\section{A. Pengaruh Online Travel Agent dalam Pemesanan Kamar Hotel}

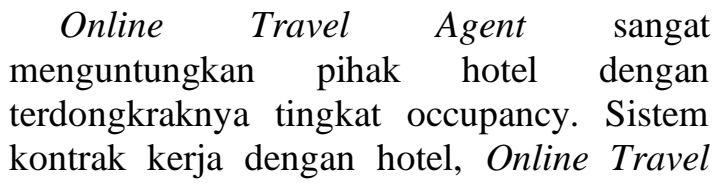

Agent tersebut dipastikan selalu minta harga di bawah rate atau yang sudah ditetapkan. Biasanya, Online Travel Agent meminta hotel mengurangi harga mulai 10\% hingga $20 \%$ dari daftar harga. Diskon tersebut dimanfaatkan aplikasi travel online untuk memberikan promo harga yang lebih murah ke customer. Sehingga, customer bisa mendapat harga yang lebih murah daripada booking langsung di Hotel. Untuk potongan harga, setiap hotel memiliki kebijakan berbeda. Biasanya, potongan harga disepakati sesuai periode tertentu. Misalnya, jika pada periode low season Online Travel Agent dan hotel bisa memberi potongan harga besar dibanding ketika musim liburan. Sesuai dengan perjanjian atau kontrak, customer akan mendapatkan harga kamar yang lebih murah.

Misalnya tarif booking hotel per kamar pada Hyatt Regency Yogyakarta ditetapkan sebesar Rp 1.500.000 untuk harga kamar standard. Disepakati pihak Online Travel Agent meminta potongan harga hingga 15\% atau sebesar Rp 300.000. Dari total diskon Rp 300.000 pihak aplikasi OTA memberi diskon untuk customer online hanya Rp 100.000 hingga Rp 120.000. Selisih potongan harga dari hotel terhadap Online Travel Agent tersebut menjadi pemasukan bagi pihak pengelola aplikasi.

Dengan perjanjian tersebut, otomatis pihak hotel harus siap mengurangi laba mereka demi memenuhi syarat kerja sama. Pengurangan laba berbeda berdasar proses negosiasi antara pihak hotel dengan manajemen OTA. Fasilitas dan jarak ke pusat keramaian menjadi salah satu pertimbangan kerja sama dua pihak tersebut. Secara laba memang hotel mendapat lebih sedikit dari aplikasi online, tapi intensitas dapatnya lebih sering. Pihak hotel juga diuntungkan dengan promosi melalui aplikasi online tersebut.

Sehingga, total keseluruhan dari beberapa Online Travel Agent tersebut mengalami kenaikan room night atau jumlah pemesanan kamar pada periode tahun 2018 sebesar 14.192 RN dan periode tahun 2019 sebesar 16.243 RN. Terjadi peningkatan room revenue hotel pada tahun 2018 sebesar 13.407.322.207 dan pada periode 2019 sebesar 16.848.793.076. Maka dapat disimpulkan terjadi pengaruh pada Online 
Travel Agent terhadap jumlah pemesanan di hotel Hyatt Regency Yogyakarta.

\section{B. Kerja E-Commerce Hotel Hyatt Regency Yogyakarta dalam Upaya Mendapatkan Tamu}

Setelah dibentuknya E-Commerce sebagai salah satu pilar kekuatan baru dalam mencari tamu, E-Commerce melakukan langkah sebagai upaya pemenuhan target yang dibebankan manajemen dengan cara sebagai berikut :

1. Mencari informasi mengenai Online Travel Agent yang memiliki reputasi baik ke hotel maupun para konsumennya.

2. Bekerjasama dengan Online Travel Agent yang memiliki pengalaman pembayaran yang lancar berdasarkan referensi kolega dan manager area Online Travel Agent serta membuat perjanjian saling menguntungkan.

3. Mengelola extranet dengan baik secara kreatif dan maksimal.

4. Input harga pada extranet Online Travel Agent sesuai dengan presentase occupancy hotel. Bila low occupancy maka harga diturunkan dan ketersediaan kamar ditambah, bila hunian high occupancy harga kamar dinaikan dan ketersediaan kamar diturunkan.

5. Mengadakan promosi dan potongan harga pada keadaan low season.

6. Melakukan open dan close allotment pada laman extranet Online Travel Agent dengan teliti dan seksama untuk menghindari over booking.

7. Bekerjasama dengan beberapa department dalam hal ketersediaan kamar sebagai dasar menentukan harga dan pengelolaan ketersediaan kamar, serta accounting dalam hal pembayaran kamar pada Online Travel Agent.

8. Selalu berkomunikasi dan berhubungan baik dengan pihak Online Travel Agent.

\section{Faktor yang Mempengaruhi Perubahan Pemesanan Langsung menjadi Pemesanan Online}

Berdasarkan data dari tahun 2018-2019 menunjukan bahwa pemesanan kamar di Hotel Hyatt Regency Yogyakarta menggunakan OTA semakin meningkat, berdasarkan review dari beberapa pengguna internet yang menggunakan jasa OTA dapat diketahui dengan alasan seperti pemesanan melalui OTA lebih praktis, jangkauan sangat luas, simpel dan menghemat waktu karena pembeli atau pelanggan tidak perlu menanyakan harga atau ketersediaan kamar langsung ke hotel, melainkan cukup mengakses OTA yang disukai, semua informasi yang dibutuhkan akan dapat langsung dilihat dengan jelas.

Pemesanan dapat dilakukan dimana saja baik menggunakan komputer atau smartphone selama masih terhubung dengan internet, harga lebih realistis dan sesuai dengan permintaan, waktu pemesanan lebih fleksibel sesuai dengan keinginan dikarenakan OTA berjalan selama 24 jam sehari, lebih banyak pilihan hotel sesuai keinginan dan kebutuhan. Pelanggan juga dapat mengetahui informasi mengenai hotel, jumlah kamar, fasilitas, luas kamar, jenis kamar, cara pembayaran, perjanjian quarantee payment, waktu maksimal check in dan check out dengan lebih mudah. Semua kemudahan tersebut mengakibatkan banyak tamu yang beralih dalam pemesanan dari langsung ke menggunakan jasa OTA.

\section{Hasil Analisis SWOT}

Dari analisa Matriks SWOT tersebut data yang dapat di identifikasi adalah sebagai berikut:

\section{Strategi S-O}

- Membuat promo paket untuk periode tertentu. Dengan membuat promo paket dapat membantu meningkatkan jumlah hunian pada saat periode low season atau pada hari-hari besar.

- Membuat paket kamar dengan beberapa fasilitas yang dimiliki seperti Paket kamar dan golf. Dengan membuat paket kamar beserta dengan fasilitas yang dimiliki dapat membantu memperkenalkan produk hotel yang lain dengan cepat dan maksimal.

\section{Strategi W-O}

- Melakukan kerjasama dengan beberapa perusahaan dan memberikan promo. Dengan menyandang brand ternama maka Hyatt Regency Yogyakarta mudah dikenal oleh masyarakat maupun perusahaan nasional dan 
internasional. Membuat paket promo pada kegiatan MICE dengan menggunakan fasilitas hotel secara maksimal dapat meningkatan pendapatan.

- Menjual paket kamar beserta airport transfer pada Online Travel Agent. Selama ini layanan airport transfer dijual terpisah dengan penjualan kamar. Dengan adanya paket kamar beserta airport transfer pada OTA dapat mempermudah calon konsumen mendapatkan layanan tersebut tanpa harus menghubungi hotel maupun petugas bandara.

\section{Strategi S-T}

- Memberikan tawaran atau potongan harga yang menarik kepada calon tamu yang akan menginap dengan minimal stay. Dengan memberikan potongan harga untuk calon tamu yang akan menginap long stay (minimal 3 malam) akan mempengaruhi calon konsumen dalam menentukan lama tinggalnya.

- Ikut serta dalam event-event seperti ekspo atau pameran pariwisata yang sering diadakan. Dengan mengikuti event seperti ekspo atau pameran pariwisata akan membantu memperkenalkan produk maupun promo yang dimiliki dan akan menarik perhatian calon tamu untuk datang ke hotel.

- Melakukan penanganan cepat tanggap pada review yang diberikan oleh tamu pada platform OTA. Dengan adanya review pada platform OTA dapat mempermudah konsumen dalam menentukan pilihan hotel terbaik. Review yang buruk juga akan membuat citra hotel menjadi berkurang, sehingga perlunya penangan yang optimal pada review yang diberikan oleh tamu.

\section{Strategi W-T}

- Melakukan renovasi untuk bangunan hotel terutama pada kamar. Dengan adanya perkembangan jaman, maka perlu diadakan perubahan pada dekorasi bangunan terutama kamar agar terlihat trendy dan semakin menarik calon konsumen.
- Melakukan permintaan maaf dan memberikan pelayanan yang baik untuk tamu (in-house) yang memberikan review buruk pada platform OTA. Apabila ada tamu yang tidak puas dengan pelayanan yang diberikan hotel dan menulis review buruk maka harus mendapatkan pelayanan terbaik dan berusaha untuk memperbaiki citra hotel pada tamu.

\section{E. Analisis Strategi Berdasarkan Matriks Internal dan Eksternal}

Dari hasil analisis nampak bahwa posisi Hotel Hyatt Regency Yogyakarta sebagai hotel bintang 5 terletak pada kuadran I yang menunjukan bahwa Hotel Hyatt Regency Yogyakarta menghadapi beberapa peluang dan mempunyai berbagai kekuatan yang mendorong untuk mendapatkan peluangpeluang tersebut. Letak hotel Hyatt Regency Yogyakarta yang berada pada kuadran I menunjukan bahwa strategi yang dilakukan oleh pihak manajemen hotel Hyatt Regency Yogyakarta adalah strategi agresif, dengan keunggulan biaya menyeluruh, melalui seperangkat kebijakan fungsional yang ditujukan pada sasaran utama. Pengendalian biaya secara agresif, efisien, efektif, berkelanjutan. Tindakannya bukan hanya mengembangkan tetapi lebih baik dan mudah serta memberikan pelayanan terbaik dengan fasilitas yang mendukung, meskipun memiliki bangunan yang lama dan terkesan tidak mengikuti jaman, namun dengan keunggulannya tetap saja kondisi Hotel Hyatt Regency Yogyakarta merupakan hotel bintang 5 yang menjadi salah satu hotel favorit di kota Yogyakarta.

Strategi pertumbuhan melalui konsentrasi vertical dapat dilakukan dengan cara megambil alih fungsi yang sebelumnya disediakan oleh pemasok (backward integration) atau dengan cara mengambil alih fungsi distributor (forward integration). Hal ini merupakan strategi utama untuk perusahaan yang memiliki posisi kompetitif pasar yang kuat (high market share) dalam industry yang berdaya tarik tinggi (Rangkuti, 2008:44). Melihat posisi kompetitif Hotel Hyatt Regency Yogyakarta yang kuat sebagai hotel dengan brand Hyatt yang sudah sangat terkenal di seluruh dunia, maka strateginya adalah strategi pertumbuhan konsentrasi 
melalui integrasi vertical dengan mengambil alih fungsi distibusi (forward integration) dengan melalui pendekatan sumberdaya internal agar dapat meningkatkan kekuatan bisnisnya atau posisi kompetitifnya Hotel Hyatt Regency Yogyakarta harus melakukan upaya-upaya untuk mengontrol kualitas produk yang menjadi kekuatannya, melakukan perbaikan dan renovasi untuk bangunannya serta memaksimalkan fasilitas yang dimiliki.

\section{F. Strategi Promosi pada Online Travel Agent (Booking.com dan Traveloka)}

Salah satu strategi pemasaran yang digunakan oleh pihak hotel adalah bekerja sama dengan Online Travel Agent untuk meningkatkan penjualan kamar. Pemasaran melalui aplikasi Online Travel Agent seperti Booking.com dan Traveloka. Penjualan kamar melalui OTA terbukti dapat meningkatkan hunian kamar sehingga peran serta dukungan dari pihak hotel baik dari karyawan maupun manajemen harus ditingkatkan, sehingga tujuan untuk meningkatkan penjualan tercapai. Online Travel Agent mampu meningkatkan tingkat hunian kamar hotel bila dikelola dengan serius, seksama, benar, teliti, terus menerus dan kreatif dalam penentuan harga (dynamic rate) dari hari ke hari.

Pengunjung yang datang memesan kamar melalui aplikasi OTA terutama Booking.com dan Traveloka semakin meningkat setiap tahunnya. Booking.com banyak diminati tamu yang berasal dari mancanegara sedangkan traveloka lebih diminati oleh masyarakat Indonesia sendiri. Dengan adanya Online Travel Agent dapat mempermudah promosi bukan hanya menjual voucher kamar hotel tetapi hotel harus memaksimalkan fasilitas yang dimiliki untuk dapat dinikmati oleh tamu. Berikut beberapa strategi pemasaran pada Online Travel Agent berdasarkan analisis yang telah dilakukan oleh penulis :

1. Membuat promo paket untuk periode tertentu

2. Membuat paket kamar dengan fasilitas yang dimiliki

3. Memberikan discount dengan jumlah minimum stay
4. Melakukan penanganan cepat tanggap pada review yang diberikan oleh tamu pada platform OTA.

Jadi, berdasarkan hasil analisis strategi menggunakan matriks SWOT dan matriks eksternal internal diperoleh beberapa strategi yang sama antara kedua analisis strategi tersebut. Sehingga dapat dikatakan bahwa hasil analisis yang penulis lakukan menggunakan kedua matriks tersebut saling berkaitan (link and match) serta mendukung satu dengan yang lainnya untuk meningkatkan strategi pemasaran hotel Hyatt Regency Yogyakarta khususnya pada Online Travel Agent.

\section{Kesimpulan}

1. Penjualan kamar melalui OTA terbukti dapat meningkatkan hunian kamar sehingga peran serta dan dukungan dari pihak hotel baik dari karyawan maupun management harus ditingkatkan, sehingga tujuan untuk meningkatkan penjualan tercapai. Online Travel Agent mampu meningkatkan tingkat hunian kamar hotel bila dikelola dengan serius, seksama, benar, teliti, terus menerus dan kreatif termasuk dalam penentuan harga (dinamic rate) day by day. Keuntungan penjualan menggunakan OTA sangat banyak dibandingkan kerugian dikarenakan jangkauan yang luas serta tidak dibatasi oleh waktu dan tempat selama masih terhubung dengan jaringan internet. Selain itu juga OTA dapat digunakan sebagai media promosi yang baik serta tidak memiliki batasan negara atau dapat menjangkau seluruh dunia. E-Commerce harus mampu mengikuti perkembangan jaman dan teknologi serta keinginan tamu yang serba praktis dan mudah dengan hasil maksimal.

2. Berdasarkan data dari tahun 2018-2019 menunjukan bahwa pemesanan kamar di Hotel Hyatt Regency Yogyakarta menggunakan OTA semakin meningkat, berdasarkan review dari beberapa pengguna internet yang menggunakan jasa OTA dapat diketahui dengan alasan seperti pemesanan melalui OTA lebih praktis, jangkauan sangat luas, simpel dan menghemat waktu karena pembeli atau pelanggan tidak perlu menanyakan harga atau ketersediaan kamar langsung ke hotel, 
melainkan cukup mengakses OTA yang disukai, semua informasi yang dibutuhkan akan dapat langsung dilihat dengan jelas.

3. Hasil identifikasi faktor strategi internal dan faktor strategi eksternal maka diketahui bahwa hotel Hyatt Regency Yogyakarta memiliki posisi kompetitif pasar yang kuat dalam persaingan dengan hotel bintang lima lainnya. Hal ini menunjukkan hotel Hyatt Regency Yogyakarta harus tetap melakukan upayaupaya meningkatkan kualitas produk, fasilitas dan pelayanan. erdapat empat alternatif strategi promosi yang dapat diterapkan hotel Hyatt Regency Yogyakarta pada Online Travel Agent berdasarkan analisis SWOT untuk meningkatkan jumlah pemesanan kamar yaitu: Membuat promo paket untuk periode tertentu, membuat paket kamar dengan fasilitas yang dimiliki, memberikan discount dengan jumlah minimum stay, melakukan penanganan cepat tanggap pada review yang diberikan oleh tamu pada platform OTA.

\section{References}

Australian Tourism Data Wirehouse. (2013). Tutorial 39a Online Travel Agents 101. Australia: Australian Tourism Data Warehouse.

Bagyono. (2012). Pariwisata dan Perhotelan. Bandung: Alfabeta.

Chaffey, Dave. (2009). E-Business and $E$ Commerce Management (4th. Edition Ed.). England: Pearson.

Damarjati. (2011). Istilah-Istilah Dunia Pariwisata. Jakarta: Pradyna Paramita.

Hendiyati, L. (2019). Pengaruh Online Travel Agent Terhadap Pemesanan Kamar Di Hotel
Mutiara Malioboro Yogyakarta. Jurnal Media Wisata. Volume 17 nomer 1.

Istijab. (2012). Pekembangan Hotel Di Yogyakarta. Yogyakarta: Bernas

Kotler dan Keller. (2007). Manajemen Pemasaran. Terjemahan oleh Bob Sabran. Edisi 12 jilid 1. Jakarta: PT.Indeks.

Kotler, P dan Amstrong, G. (2008). Prinsip-prinsip Pemasaran. Terjemahan oleh Bob Sabran. Edisi 12 jilid 1. Jakarta: Penerbit Erlangga.

Kotler, P dan Amstrong, G. (2012). Prinsip-prinsip Pemasaran. Terjemahan oleh Bob Sabran. Edisi 13 jilid 1. Jakarta: Penerbit Erlangga.

Laudon, Kenneth C. \& Traver, Carol Guercio. (2012). E-Commerce 2012 (Business, Technology, Society). Eight Edition. Pearson.

Malla. (2016). Online Travel Agent. http://www.quora.com/What-arethecomponent-of-OTA-model-onlinetravel/

O’Brien dan Marakas. (2011). Management Information System. Illinois Chichago: Mc Graw-Hill/Irwin Northwestern University

Rangkuti, F. (2008). Analisis SWOT: Teknik Membedah Kasus Bisnis. Jakarta: Gramedia Pustaka Utama.

Rangkuti, F. (2013). Teknik Membedah Kasus Bisnis Analisis SWOT Cara Perhitungan Bobot, Rating, dan OCAI. Jakarta. Gramedia Pustaka Utama.

Rangkuti, F. (2015). Teknik Membedah Kasus Bisnis Analisis SWOT. Gramedia Pustaka Utama.

Sofjan, Assauri. Manajemen Pemasaran Dasar, Konsep dan Strategi. Edisi 1 Hal 198. Jakarta: Raja Grafindo 2018.

Supriyanto, Slamet. (2016). Peran Online Travel Agent dalam meningkatkan Hunian Kamar di Hotel Mutiara Malioboro Yogyakarta. Semarang: STIEPARI

Tripomo, T dan Udan. (2005). Manajemen Strategi. Bandung: Rekayasa Sains 